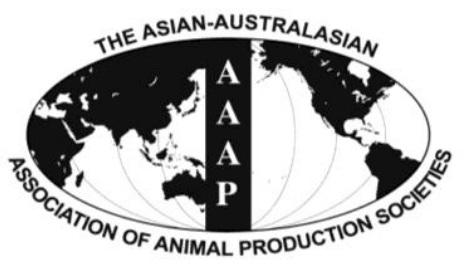

Asian-Aust. J. Anim. Sci.

Vol. 25, No. 11 : 1611-1616 November 2012

http://dx.doi.org/10.5713/ajas.2012.12234

www.ajas.info

pISSN 1011-2367 elSSN 1976-5517

\title{
Effect of Dietary Sodium Nitrate Consumption on Egg Production, Egg Quality Characteristics and Some Blood Indices in Native Hens of West Azarbaijan Province
}

\author{
H. Safary and M. Daneshyar* \\ Department of Animal Science, Faculty of Agriculture, Urmia University, Urmia, Iran
}

\begin{abstract}
The aim of the study was to evaluate the effect of sodium nitrate consumption on egg quality and quantity, and some blood parameters of native breeder hens of West Azerbaijan province. One hundred native hens were used from wk 25 to 32 of age. These birds were divided into two groups. One group was fed the control diet (CD) but the other fed the same diet supplemented with $4.2 \mathrm{~g} / \mathrm{kg}$ sodium nitrate (ND). After 2 wks of adaptation, eggs were collected daily and egg mass and egg production were measured weekly for five weeks. To assess the egg quality parameters, two eggs from each replicate pen were collected for three consecutive days each week. At the end of experimental period (wk 32 of age), blood samples of 5 birds per replicate were collected from the wing vein into anticoagulant tubes. Dietary sodium nitrate didn't affect the egg production, shell stiffness, shell thickness and Haugh unit ( $>0.05$ ) but it decreased the both egg production and egg mass during the last three weeks (wks 30, 31 and 32) (p<0.05). Furthermore, a treatment effect was observed for yolk colour $(p<0.05)$. Both the egg production and egg mass were increased over time $(p<0.05)$. No significant treatment $\times$ time interaction was observed for egg weight, egg production and egg mass ( $p>0.05)$. No effect of time or treatment $\times$ time were observed for shell stiffness $(p>0.05)$. Over time, shell thickness was decreased while Haugh unit increased $(\mathrm{p}<0.05)$. None of the blood TP and TG or the activity of ALT, AST and LDH enzymes were affected by dietary consumption of sodium nitrate at wk 32 of age ( $>0.05)$. Sodium nitrite decreased both the TAC and TC at wk 32 of age ( $<<0.001)$. It was concluded that the lower body antioxidant capacity of nitrate fed birds resulted in the lower performance (egg weight, egg production and egg mass). (Key Words: Nitrate, Performance, Blood Antioxidant Indices, Enzyme Activities, Blood Cholesterol, Hen)
\end{abstract}

\section{INTRODUCTION}

Changes in patterns of agricultural practice, food processing and industrialization have resulted in accumulation of nitrates and nitrites in the environment. Intensive farming practice increased the use of nitrogenbased fertilizers, particularly for corn, vegetables, other row crops and forages (Chow and Hong, 2002). Livestock and poultry production as well as urban sewage treatment also contribute nitrogenous wastes to the soil and water. Bacteria present in the soil, water, feed and foods are capable of utilizing these nitrogenous compounds to synthesize nitrates and nitrites de novo via heterotrophic nitrification and hence nitrate reduction (Tannenbaum et al., 1978). Either of nitrate or nitrite results in formation of methemoglobin, a substance that interferes with the ability of blood cells to

\footnotetext{
* Corresponding Author: Mohsen Daneshyar. Tel: +984412 772341, Fax: +984412779558, E-mail: m.daneshyar@urmia.ac.ir Submitted Apr. 29, 2012; Accepted Jun. 19, 2012; Revised Jul. 1, 2012
}

carry oxygen. Because of its effect on blood cells, formation of methemoglobin is the most recognizable and detectable sign of nitrite and nitrate toxicity in humans (National Toxicology program, 2001). Fatal toxic methemoglobinemia has been reported due to high levels of nitrite in drinking water or occupational exposure to nitrite (Ger et al., 1996). A number of biochemical changes, functional impairments and histopathological lesions have been observed in nitrite-treated rats. Orally administration of 25 to $100 \mathrm{mg}$ sodium nitrite per $\mathrm{kg}$ diet to $\mathrm{Balb} / \mathrm{c}$ mice for $21 \mathrm{~d}$ has resulted in a dose dependent decrease of lymphocyte percentages, concanavalin A and lipopolysaccharide-induced lymphocyte proliferation, natural killer cell activity against WEHI-164 target cells, as well as $\operatorname{IgM}$ and $\operatorname{IgG}$ titers against injected sheep erythrocytes (Chow and Hong, 2002). Rat exposed to sodium nitrate in drinking water developed cyanosis and smooth muscle relaxation (National Toxicology program, 2001). Histopathological examinations revealed that nitrite 
treated mice developed massive liver necrosis (Chow and Hong, 2002). Oxidative damage which is a consequence of excessive oxidative stress and/or insufficient antioxidant potential (Chow, 1979; 1991; Sies, 1986; Halliwell, 1987), is the other consequence of nitrate or nitrite treating in animals. There are very limited reports regarding the possible detrimental effects of nitrate or nitrite on poultry performance. Water nitrate has been reported to decrease the growth rate of animals especially broiler chickens (Barton et al., 1986). In slow growing native breed (Balady), dietary sodium nitrate $(4.2 \mathrm{gr} / \mathrm{kg})$ have retarded growth and caused methaemoglobinaemia (Atef et al., 1991). No information is available about the negative effects of nitrate consumption on lying performance, blood indices and enzymes activities in broiler breeder. Hence, recent experiment was conducted to investigate the effects of dietary sodium nitrite consumption on egg quality and quantity parameters and some blood indices of native breeder hens of West Azerbaijan hens. Pyruvate and lactate are the end products in the process of glycolysis (Mannen et al., 1997). Lactate dehydrogenase (LDH) is an oxidoreductase enzyme which catalyzes the interconversion of lactate and pyruvate. When disease or injury affects tissues containing $\mathrm{LDH}$, the cells release $\mathrm{LDH}$ into the bloodstream and caused the higher levels of LDH than normal levels. Therefore, LDH is the most often indices to evaluate the of tissues damages hence LDH activity was investiageted as the liver damage or toxicity indicator (Daneshyar et al., 2010). Moreover both the aspartate aminotransferase (AST) and alanine aminotransferase (ALT) enzymes are released to the blood stream during the liver damages (Shim et al., 2004; Daneshyar et al., 2009) and hence were assessed in recent experiment. Liver injury such as massive liver necrosis (Chow and Hong, 2002) has been reported in nitrite toxicity.

\section{MATERIALS AND METHODS}

One hundred twenty-weeks-old hens (West Azerbaijan native hens) were used in this experiment. West Azerbaijan native hens are held in West Azerbaijan native hen support and breeding center which have been selected for egg production and body weight gain during 14 generations. These birds were divided between 10 replicate pens with 10 birds each. Five pens were allocated to each experimental group. One group was fed the control diet and the other was fed the same control diet supplemented with $4.2 \mathrm{~g} / \mathrm{kg}$ sodium nitrate (Atef et al., 1991), and defined as the CD and ND groups respectively. Environmental temperature was set at $21^{\circ} \mathrm{C}$. Sixteen $\mathrm{h}$ light and $8 \mathrm{~h}$ dark were used during the experimental period. Each bird was given $110 \mathrm{~g}$ of the experimental diets per day for seven weeks (Table 1).
Table 1. Composition of experimental diets

\begin{tabular}{lcc}
\hline Ingredients (\%) & $\begin{array}{c}\text { Control } \\
\text { diet }\end{array}$ & $\begin{array}{c}\text { Sodium nitrate } \\
\text { diet }\end{array}$ \\
\hline Corn (8\% protein) & 59.88 & 59.88 \\
Soybean meal (44\% protein) & 21.50 & 21.50 \\
Soybean oil & 3.75 & 3.75 \\
Dicalcium phosphate & 1.50 & 1.50 \\
Oyster shell & 11.64 & 11.64 \\
Dl-methionine & 0.11 & 0.11 \\
Vitamin and mineral premix ${ }^{1}$ & 0.50 & 0.50 \\
Salt & 0.37 & 0.37 \\
Sand & 0.75 & 0.33 \\
Sodium nitrate & 0.00 & 0.42 \\
Total & 100 & 100 \\
Calculated analysis & & \\
ME (kcal/kg) & 2,800 & 2,800 \\
CP $(\%)$ & 14.00 & 14.00 \\
Calcium (\%) & 3.40 & 3.40 \\
Available phosphorus $(\%)$ & 0.34 & 0.34 \\
Sodium $(\%)$ & 0.18 & 0.18 \\
Arginine $(\%)$ & 0.74 & 0.74 \\
Methionine+cystine $(\%)$ & 0.59 & 0.59 \\
Lysine $(\%)$ & 0.68 & 0.68 \\
Tryptophan $(\%)$ & 0.14 & 0.14 \\
\hline Suppled & &
\end{tabular}

${ }^{1}$ Supplied per kilogram of diet: retinol, 9,000 IU; cholecaciferol, 2,000 IU; alpha tocopherol, $181 \mathrm{IU}$; cyanocobalamin, $15 \mu \mathrm{g}$; riboflavin, 4.4 $\mathrm{mg}$; niacin, $22 \mathrm{mg}$; choline, $840 \mathrm{mg}$; biotin, $30 \mu \mathrm{g}$; thiamine, $4 \mathrm{mg}$; calcium, $99 \mathrm{mg}$; zinc, $84 \mathrm{mg}$; manganese, $60 \mathrm{mg}$; iodine, $0.922 \mathrm{mg}$; selenium, $0.2 \mathrm{mg}$; copper, $10 \mathrm{mg}$.

Before the experiment, the birds were adopted to the experimental diets for two weeks. The experimental diets were formulated to meet or exceed the broiler breeder requirements (Lesson and Summers, 2005). Hens were given free access to water. Then eggs were collected daily for five weeks, and their related egg mass and egg production were calculated and reported weekly. Two eggs from each pen collected for assess the egg quality parameters (shell stiffness, shell thickness, yolk color and haugh units) at first 3 consecutive days of each week (Saturday, Sunday and Monday). Egg shell thickness was measured using a micrometer (OSK-13496, Ogawa Seiki CO., LTD. Japan). Albumin height was determined using a special instrument (OSK-13471, Ogawa Seiki CO., LTD. Japan) and used for calculation of Haugh unit according the formula of Eisen et al. (1962) that presented below. Shell stiffness and yolk color were measured by egg shell intensity meter (Model 1618, Tokyo, Japan) and Roche color fan system respectively. At the end of the experiment (wk 32 of age), one hen per pen selected randomly and used for taking the blood samples. Blood samples were taken from the wing vein by venoject and transferred to anticoagulant tubes (EDTA). Then the blood samples were 
centrifugated at 5,000 rpm for $5 \mathrm{~min}$. The plasma samples were stored at $-20^{\circ} \mathrm{C}$ until the later analysis. Plasma samples were thawed in lab and their total antioxidant capacity were determined using Randox total antioxidant status test kit (Randox Laboratories Ltd, UK). Moreover, plasma total protein, total cholesterol and triglyceride contents and LDH, AST, and ALT activities were determined enzymatically by Pars Azmon kits (Pars Azmon Co., Iran) using a spectrophotometer (Alcyon 300, USA). The experimental data were analyzed based a completely randomized design with 2 treatments and 5 replicate each. The blood indices data were subjected to GLM procedure of SAS (SAS Institute, 2002) whereas egg quantity and quality parameters were analyzed according the MIXED procedure of SAS by repeated measures. Duncan's multiple range test was used to separate the means when treatment means were significant $(\mathrm{p} \leq 0.05)$.

$$
H U=100 \log \left[H-\frac{\sqrt{G}\left(30 W^{.0 .37}-100\right)}{100}+1.9\right]
$$

$$
\begin{aligned}
& \text { HU = Haugh unit } \\
& \text { W = Egg weight }(g) \\
& H=\text { Albumin height } \\
& \mathrm{G}=32.2
\end{aligned}
$$

\section{RESULTS AND DISCUSSION}

The effect of dietary sodium nitrate consumption on egg weight, egg production and egg mass are shown in Table 2. No effect of sodium nitrate was observed on egg production and egg mass during wks 28 and 29 of age ( $>0.05$ ), but sodium nitrate decreased the both egg production and egg mass afterwards (during wks 30, 31 and 32 of age) ( $p<$ $0.05)$. Moreover both the egg production and egg mass were increased over time $(\mathrm{p}<0.05)$. Dietary sodium nitrite declined the egg weight $(\mathrm{p}<0.001)$ at the last two weeks of experimental period $(\mathrm{p}<0.01)$. No significant treatment $\times$ time interaction was observed for egg weight, egg production and egg mass ( $p>0.05)$. The time increasing effect on egg production is related to the normal increase trend of egg production before peak (wk 28). This increasing trend in egg production has caused the same trend for egg mass. We started the experiment on wk 26 and egg collection on wk 28 of age.

Dietary sodium nitrate didn't affect the shell stiffness, shell thickness and Haugh unit (Table 3) ( $>0.05$ ). Furthermore, no effect of time or treatment $\times$ time were observed for shell stiffness $(p>0.05)$. Over time, shell

\begin{tabular}{|c|c|c|c|c|}
\hline & Treatment & Egg weight (gr) & Egg mass (gr) & Egg production (\%) \\
\hline \multirow[t]{4}{*}{ Wk 28} & $\mathrm{CD}$ & 51.77 & 23.53 & $43.02^{\mathrm{a}}$ \\
\hline & ND & 47.48 & 20.54 & $40.14^{\mathrm{a}}$ \\
\hline & Pooled SEM & 1.46 & 1.81 & 3.30 \\
\hline & $\mathrm{p}$ value & 0.15 & 0.44 & 0.68 \\
\hline \multirow[t]{4}{*}{ Wk 29} & $\mathrm{CD}$ & 52.16 & 28.55 & $53.14^{\mathrm{a}}$ \\
\hline & ND & 49.74 & 22.55 & $43.71^{\mathrm{a}}$ \\
\hline & Pooled SEM & 1.36 & 2.05 & 3.56 \\
\hline & $\mathrm{p}$ value & 0.40 & 0.15 & 0.20 \\
\hline \multirow[t]{4}{*}{ Wk 30} & $\mathrm{CD}$ & 52.35 & $29.70^{\mathrm{a}}$ & $56.55^{\mathrm{a}}$ \\
\hline & ND & 50.62 & $23.01^{\mathrm{b}}$ & $44.0^{\mathrm{b}}$ \\
\hline & Pooled SEM & 0.88 & 1.57 & 2.98 \\
\hline & $\mathrm{p}$ value & 0.36 & 0.021 & 0.025 \\
\hline \multirow[t]{4}{*}{ Wk 31} & $\mathrm{CD}$ & $53.90^{\mathrm{a}}$ & $33.53^{\mathrm{a}}$ & $62.0^{\mathrm{a}}$ \\
\hline & ND & $51.77 \mathrm{~b}$ & $27.62 b$ & $47.0^{\mathrm{b}}$ \\
\hline & Pooled SEM & 0.56 & 1.40 & 3.22 \\
\hline & $\mathrm{p}$ value & 0.003 & 0.023 & 0.008 \\
\hline \multirow[t]{4}{*}{ Wk 32} & $\mathrm{CD}$ & $55.84^{\mathrm{a}}$ & $34.69^{\mathrm{a}}$ & $64.0^{\mathrm{a}}$ \\
\hline & ND & $50.39^{\mathrm{b}}$ & $25.58 b$ & $46.0^{\mathrm{b}}$ \\
\hline & Pooled SEM & 1.21 & 2.20 & 4.47 \\
\hline & $\mathrm{p}$ value & 0.01 & 0.03 & 0.02 \\
\hline \multirow[t]{3}{*}{ Source of variation } & Treatment & 0.0007 & 0.02 & 0.05 \\
\hline & Time & 0.10 & 0.0001 & 0.001 \\
\hline & Treatment $\times$ time & 0.43 & 0.54 & 0.24 \\
\hline
\end{tabular}
thickness was decreased while Haugh unit increased $(\mathrm{p}<$ 0.05). Although a treatment effect was observed for yolk colour $(p<0.05)$, no significant differences were observed

Table 2. Weekly egg production, egg mass and egg weight of birds fed the control diet (CD) or diets supplemented with $4.2 \mathrm{~g} / \mathrm{kg}$ (ND)

\footnotetext{
${ }^{\mathrm{a}-\mathrm{b}}$ Means in each column and time with no common superscript differ significantly $(\mathrm{p}<0.05)$.
} 
Table 3. Weekly shell stiffness, shell thickness, haugh unit and yolk colour of eggs ${ }^{1}$ from birds fed the control diet (CD) or diet supplemented with $4.2 \mathrm{~g} / \mathrm{kg}$ sodium nitrate (ND)

\begin{tabular}{|c|c|c|c|c|c|}
\hline & Treatment & Shell stiffness $\left(\mathrm{kg} / \mathrm{cm}^{2}\right)$ & Shell thickness $(\mu \mathrm{m})$ & Haugh unit & Yolk color \\
\hline \multirow[t]{4}{*}{ Wk 28} & $\mathrm{CD}$ & 2.24 & 31.60 & 83.80 & 5.06 \\
\hline & ND & 2.26 & 30.53 & 80.56 & 5.63 \\
\hline & SEM & 0.19 & 0.49 & 1.72 & 0.20 \\
\hline & $\mathrm{p}$ value & 0.95 & 0.28 & 0.35 & 0.15 \\
\hline \multirow[t]{4}{*}{ Wk 29} & $\mathrm{CD}$ & 2.10 & 29.20 & 81.66 & 6.37 \\
\hline & ND & 2.87 & 29.30 & 87.33 & 6.84 \\
\hline & SEM & 0.34 & 0.52 & 1.590 & 0.12 \\
\hline & $\mathrm{p}$ value & 0.26 & 0.93 & 0.070 & 0.08 \\
\hline \multirow[t]{4}{*}{ Wk 30} & $\mathrm{CD}$ & 1.93 & 26.74 & 85.51 & 6.33 \\
\hline & ND & 2.19 & 29.57 & 83.04 & 6.80 \\
\hline & SEM & 0.14 & 0.97 & 1.05 & 0.15 \\
\hline & $\mathrm{p}$ value & 0.37 & 0.14 & 0.24 & 0.10 \\
\hline \multirow[t]{4}{*}{ Wk 31} & $\mathrm{CD}$ & 2.14 & 25.14 & 87.03 & 6.53 \\
\hline & ND & 2.42 & 25.57 & 86.49 & 6.93 \\
\hline & SEM & 0.15 & 0.48 & 1.35 & 0.13 \\
\hline & $\mathrm{p}$ value & 0.36 & 0.66 & 0.84 & 0.13 \\
\hline \multirow[t]{4}{*}{ Week 32} & $\mathrm{CD}$ & 2.18 & 25.80 & 87.24 & 6.55 \\
\hline & ND & 2.40 & 25.53 & 86.72 & 6.94 \\
\hline & SEM & 0.15 & 0.46 & 1.44 & 0.13 \\
\hline & $\mathrm{p}$ value & 0.45 & 0.77 & 0.87 & 0.12 \\
\hline \multirow[t]{3}{*}{ Source of variation } & Treatment & 0.34 & 0.38 & 0.72 & 0.02 \\
\hline & Time & 0.23 & 0.0001 & 0.008 & 0.0001 \\
\hline & Treatment $\times$ time & 0.92 & 0.41 & 0.03 & 0.89 \\
\hline
\end{tabular}

${ }^{1}$ Thirty eggs per treatment (six eggs per replicate) were used for egg quality indices.

between the treatment during different weeks $(\mathrm{p}>0.05)$. Decreasing trend of shell thickness over time in recent experiment is possibly related to lower availability of calcium for more produced eggs. Because both the egg production and egg mass increased by time. The increased yolk color content of both groups during time is because of higher content of dietary pigments. Before the experiment, a diet with lower corn (wheat-corn-soybean meal diets) was used which was changed to experimental diets with higher corn content (corn-soybean diets). Higher color score of yolk is well recognized by dietary supplementation of pigments (Esfahani-Mashhour et al., 2009). In addition, higher color index of eggs from sodium nitrate fed birds could be connected to the higher access to the pigments in their smaller eggs (lower egg weight). No report is available regarding the plasma TP or TG changes by nitrate or nitrite consumption in birds. We expected some changes in the metabolism of TP and TG or the enzyme activities, because nitrate or nitrite results in formation of methemoglobin and low ability of blood cells to carry oxygen (Ger et al., 1996) and hypoxemia consequently. But as shown in Table 4, none of the plasma TP and TG or the activity of ALT, AST and LDH enzymes (wk 32 of age) were affected by dietary consumption of sodium nitrate at the end of experiment $(\mathrm{p}>0.05)$.

Sodium nitrite decreased both the TAC and TC at wk 32 of age $(p<0.001)$. Lower plasma TAC content of ND birds is due to the higher peroxide production. Peroxide is a reactive oxygen specious (ROS) that cause oxidative damage in body. Excessive levels of ROS or proxynitrite

Table 4. Plasma total antioxidant capacity (TAC), total cholesterol (TC), total protein (TP) and total triglyceride (TG) and plasma activities of lactate dehydrogenase (LDH), aspartate aminoteransferase (AST) and alanine aminotransferase (ALT) of birds $^{1}$ fed the control diet (CD) or diets supplemented with 4.2 $\mathrm{g} / \mathrm{kg}(\mathrm{ND})$ at the end of experiment (wk 32)

\begin{tabular}{lcrrl}
\hline Parameters & CD & ND & $\begin{array}{r}\text { Pooled } \\
\text { SEM }\end{array}$ & p value \\
\hline TAC $(\mathrm{mmol} / \mathrm{L})$ & $1.06^{\mathrm{a}}$ & $0.66^{\mathrm{b}}$ & 0.08 & 0.0001 \\
$\mathrm{TC}(\mathrm{mg} / \mathrm{dl})$ & $151.50^{\mathrm{a}}$ & $94.00^{\mathrm{b}}$ & 10.36 & 0.0001 \\
$\mathrm{ALT}(\mathrm{U} / \mathrm{L})$ & 8.750 & 6.400 & 0.85 & 0.18 \\
$\mathrm{AST}(\mathrm{U} / \mathrm{L})$ & 184.00 & 187.20 & 8.44 & 0.86 \\
$\mathrm{TP}(\mathrm{gr} / \mathrm{dl})$ & 5.500 & 4.94 & 0.19 & 0.10 \\
$\mathrm{TG}(\mathrm{mg} / \mathrm{dl})$ & 699.00 & 569.00 & 95.07 & 0.53 \\
LDH $(\mathrm{U} / \mathrm{L})$ & 501.30 & 718.80 & 76.95 & 0.17
\end{tabular}

a-b Means in each row with no common superscript differ significantly $(\mathrm{p}<0.05)$.

${ }^{1}$ Five birds per treatment (one per replicate) were used for determination of blood indices. 
results in oxidative stress and causing severe damage to cellular components and even lipid peroxidation (Seven et al., 2010).

Rather than peroxide, nitrites and nitrates are the key oxidation products as well as ready sources of NO, which in turn react rapidly with superoxide to form reactive $\mathrm{ONOO}^{-}$ (proxynitrite) (Chow et al., 2001). Proxynitrite causes the formation of methemoglobine, oxidative damages and consequently body stress and hypoxia. This process decreases the ATP production and as a result diminishes the egg mass and egg production that observed in our study. Formation of methemoglobin interferes with the ability of blood cells to carry oxygen. Fatal toxic methemoglobinemia has been indicated due to high levels of nitrite in drinking water or occupational exposure to nitrite (Ger et al., 1996). Declined plasma TC of nitrate fed birds in recent experiment may be because of cholesterol oxidation by produced free radicals from nitric oxide (Drexler et al., 1991). Liao et al. (1995) have shown that oxidized LDL decreases the expression of endothelial nitric oxide synthase. Moreover their reports indicated that nitric oxide generation is decreased in hypercholesterolemia.

The results of this study indicate that consumption of sodium nitrate in native hens diminishes the body antioxidant capacity and then induces hypoxia which is consequently decreases the egg weight, egg production and egg mass. Furthermore, declined plasma TC of nitrate fed birds possibly is due to cholesterol oxidation effect of produced free radicals from nitric oxide. Higher yolk color index of sodium nitrate fed birds related to the higher availability of pigments for their smaller eggs.

\section{AKNOWLEDGMENTS}

We sincerely thank $\mathrm{Mr}$ Amir Mansor Vatankhah (Deptartment of Drug Applied Research Center, Tabriz University of Medical Sciences, Tabriz, Iran) for his helps in determination of blood indices.

\section{REFERENCES}

Ames, B. N. 1983. Dietary carcinogens and anticarcinogens oxygen radicals and degenerative diseases. Science 221:12561264.

Atanasova-Goranova, V. K., P. I. Dimova and G. T. Pevicharova. 1997. Effect of food products on endogenous generation of $\mathrm{N}$ nitrosamines in rats. Br. J. Nutr. 78:335-345.

Atef, M Abo-Norage, M. A., M. S. Hanafy and A. E. Agag. 1991. Pharmacotoxicological aspects of nitrate and nitrite in domestic fowls. Br. Poult. Sci. 32:399-404.

Barton, T. L., L. H. Hileman and T. S. Nelson. 1986. A Survey of water quality on Arkansas broiler farms and meeting poultry Health and Condemnation, Univ. Arkansas, Fayetteville, A R.

Chow, C. K. 2001. Vitamin E regulation of mitochondrial generation of hydrogen peroxide. Biol. Signals Receptors. 10: 112-124.

Chow, C. K. and C. B. Hong. 2002. Dietary vitamin E and selenium and toxicity of nitrite and nitrate. Toxicology 180: 195-207.

D'Ischia, M. and L. Novellino. 1996. Nitric oxide-induced oxidation of alpha-tocopherol. Bioorg. Med. Chem. 4:17471753.

Daneshyar, M., H. Kermanshahi and A. Golian. 2009. Changes of biochemical parameters and enzyme activities in broiler chickens with cold-induced ascites. Poult. Sci. 88:106-110.

Daneshyar. M., J. M. C. Geuns, J. G. Buyse, H. Willemsen, E. Decuypere, N. Everaert, H. Kermanshahi and Z. Ansari. 2010. Evaluation of steviol injection on chicken embryos: Effects on post-hatch development, proportional organ weights, plasma thyroid hormons and metabolites. J. Poult. Sci. 47:71-76.

Drexler, H., A. M. Zeiher, K. Meinzerand H. Just. 1991. Correction of endothelial dysfunction in coronary microcirculation of hypercholesterolemicpatients by Larginine. Lancet 338:1546-1550.

Eisen, E. J., B. B. Bohrenand and H. E. McKean. 1962. The haugh unit as a measure of egg albumen quality. Poult. Sci. 41:14611468.

Esfahani-Mashhour, K. S., H. Moravej, H. Mehrabani-Yeganeh and S. H. Razavi. 2009. Evaluation of coloring potential of Dietzia natronolimnaea biomass as source of canthaxanthin for egg yolk pigmentation. Asian-Aust. J. Anim. Sci. 22:254-259.

Ger, J., H. Kao, T. S. Shih and J. F. Deng. 1996. Fatal toxic methemoglobinemia due to occupational exposure to methyl nitrite. Clin. Med. J. 57:S78.

Liao, J. K., W. S. Shin, W. Y. Lee and S. L. Clark. 1995. Oxidized low-density lipoprotein decreases the expression of endothelial nitric oxide synthase. J. Biol. Chem. 270:319-324.

Marrett, L. E. and M. L. Sunde. 1986. The use of turkey and chickens as test animals for nitrate and nitrite toxicity. Poult. Sci. 68:511-519.

Mirvish, S. S. 1995. Role of N-nitroso compounds (NOC) and Nnitrosation in etiology of gastric, esophageal, nasopharyngeal and bladder cancer and contribution to cancer of known exposures to NOC. Cancer Lett. 93:17-48.

Mirvish, S. S., K. J. Reimers, B. Kutler, S. C. Chen, J. Haorah, C. R. Morris, A. C. Grandjean and E. R. Lyden. 2000. Nitrate and nitrite concentrations in human saliva for men and women at different ages and times of the day and their consistency over time. Eur. J. Cancer Prev. 9:335-342.

National Toxicology program. 2001. Toxicology and carcinogenesis studies of sodium nitrate (CAS no. 7632-00-0) in $\mathrm{F} 344 / \mathrm{N}$ rat and $\mathrm{B} 6 \mathrm{C} 3 \mathrm{~F} 1$ mice (drinking water studies), Technical Report Series No. TR-459, NIH publication No.013954, National Institutes of Environmental Health Science, Research Triangle Park, NC.

Nickerson, M. 1970. In: The Pharmacological Basis of Therapeutics (Ed. L. S. Goodman and A. Gilm1an), 4th edition. London, MacMillan, pp. 745-763.

SAS Institute. 2002. SAS users guide: Statistics. SAS Institute Inc., Cary, NC, USA.

Seven, I., T. Aksu and P. T. Seven. 2010. The effects of propolis on biochemical parameters and activity of antioxidant enzymes in broilers exposed to lead-induced oxidative stress. Asian-Aust. 
J. Anim. Sci. 23:1482-1489.

Shim, K. S., G. H. Park, C. J. Choi and C. S. Na. 2004. Decreased triglyceride and cholesterol levels in serum, liver and breast muscle in broiler by the supplementation of dietary codonopsis lanceolata root. Asian-Aust. J. Anim. Sci. 17:511-513.

Tannenbaum, S. R., D. Frett, V. R. Young, P. D. Land and W. R. Bruce. 1978. Nitrite and nitrate are formed by endogenous synthesis in the human intestine. Science 200:1487-1489.
Van Maanen, J. M., D. M. Pachen, J. W. Dallinga and J. C. Kleinjans. 1998. Formation of nitrosamines during consumption of nitrite- and amine-rich foods, and the influence of the use of mouthwashes. Cancer Detect. Prev. 22:204-212.

White, J. W. 1975. Relative significance of dietary source of nitrate and nitrite. J. Agri. Food Chem. 23:886-891. 